\title{
Article
}

\section{Revisiting the basics}

\author{
Broadhead, Ruth
}

Available at http://clok.uclan.ac.uk/31454/

Broadhead, Ruth (2020) Revisiting the basics. Journal of Prescribing Practice, 2 (1). pp. 15-16. ISSN 2631-8385

It is advisable to refer to the publisher's version if you intend to cite from the work.

10.12968/jprp.2020.2.1.15

For more information about UCLan's research in this area go to

http://www.uclan.ac.uk/researchgroups/ and search for < name of research Group>.

For information about Research generally at UCLan please go to http://www.uclan.ac.uk/research/

All outputs in CLoK are protected by Intellectual Property Rights law, including Copyright law. Copyright, IPR and Moral Rights for the works on this site are retained by the individual authors and/or other copyright owners. Terms and conditions for use of this material are defined in the policies page.

\section{CLoK}

Central Lancashire online Knowledge www.clok.uclan.ac.uk

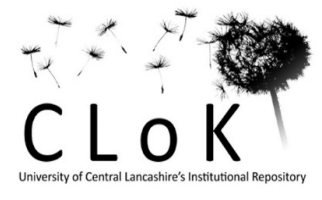




\section{Calculation skills for all prescribers - revisiting the basics}

Author:

Ruth Broadhead

Senior Lecturer

Programme Lead: Non-Medical Prescribing

University of Central Lancashire

Within the Consultation Domain of the Royal Pharmaceutical Society (2016) A competency framework for all prescribers, indicator 4.6 states that the prescriber "accurately completes and routinely checks calculations relevant to prescribing and practical dosing". Recently updated regulatory standards for prescribing dictate that numeracy \& drug calculations continue to be an essential core element of non-medical prescribing programmes, requiring the student to enhance their existing skills and expertise in respect of the medicines they aim to prescribe, within their sphere of practice (Nursing \& Midwifery Council, 2018; General Pharmaceutical Council, 2019; Health \& Care Professions Council, 2019). The following questions aim to assist both qualified prescribers and those in training to attain and maintain an aptitude for safe drug calculations by revisiting the basic principles of numeracy.

\section{Question 1}

Mrs. Smith is awaiting discharge following an uneventful appendectomy 2 days ago. You are writing a discharge prescription for analgesia. You prescribe cocodamol 30/500mg tablets, 1-2 tablets 4-6 hourly as required. You advise Mrs. Smith that no more than 8 tablets should be taken in any 24-hour period.

A) How many tablets will you prescribe for 7 days' total treatment?

B) Calculate the number of tablets Mrs. Smith requires if she takes half the maximum permissible dose for 4 days.

C) Mrs. Smith decides to use the remaining tablets by taking 2 tablets at bedtime. How many days will these last for?

\section{Question 2}

You are asked to check the dose of a patient's antihypertensive treatment. The evidence base stipulates that for your patient type, the drug should be given at 
$25 \%$ less than the standard starting dose of $10 \mathrm{mg}$ daily. The drug is available in strengths of $2.5 \mathrm{mg}, 5 \mathrm{mg}, 10 \mathrm{mg} \& 20 \mathrm{mg}$ tablets.

A) What is the daily dose that this patient should receive?

B) What should this patient be prescribed on a daily basis?

C) How many tablets in total will the patient take over a $\mathbf{3 0}$ day period?

\section{$\underline{\text { Question 3 }}$}

Janet has been admitted to hospital for intravenous antibiotics for 14 days' duration. The antibiotic is mixed in $100 \mathrm{ml}$ saline, infused over 30 minutes and is administered 6 hourly.

A) How many mls of saline will be infused over a 24-hour period?

B) How many hours of Janet's stay in hospital will she be having her IV drug?

C) Janet is discharged with oral antibiotics to be taken every $\mathbf{8}$ hours for 28 days. How many should be prescribed and dispensed for this period?

\section{Question 4}

Your patient, aged 6 years, is experiencing an acute asthma attack and requires emergency nebulisers. The dose of drug is $2.5-5 \mathrm{mg}$, repeated every $20-30$ minutes.

A) Using the above guidance, what is the maximum amount of drug in $\mathrm{mg}$ that the child can receive over a 2-hour period?

B) After 2 hours, the child receives $2.5 \mathrm{mg}$ nebulisers every 4 hours for 24 hours. How many $\mathrm{mg}$ of drug does the child receive in this 24-hour period?

C) Over this period of time, how many nebulisers in total did the child require?

\section{Question 5}

Your adult patient has a new diagnosis of moderate depression and you prescribe a Selective Serotonin Re-uptake Inhibitor (SSRI) tablet starting at a dose of $20 \mathrm{mg}$ daily. You aim to review your patient after 3 weeks.

A) How many $20 \mathrm{mg}$ tablets will you prescribe for 3 weeks? 
B) The British Medical Association (BMA) \& Royal Pharmaceutical Society (RPS) (2019) advice states to increase the dose of this drug by $20 \mathrm{mg}$ every 3-4 weeks as required up to a maximum of $40 \mathrm{mg}$ daily. How many uptitrations of this drug will therefore be permissible?

C) After 6 months of treatment on $40 \mathrm{mg}$ daily, how many tablets will the patient have consumed in total, assuming the correct daily dose is adhered to and a month being 30 days?

\section{Question 6}

You prescribe drug $P$ for your patient. It is available in $250 \mathrm{mg} / 5 \mathrm{ml}$ strength. Your patient needs $3 \mathrm{~g}$ of drug $\mathrm{P}$ per day in $2 \mathrm{x}$ divided doses.

A) How many mg per day will the patient take?

B) How many mls will the patient take at each dose?

C) For 10 days supply, how many mls will you prescribe?

\section{Answers}

Q1
a. 8 tablets $\times 7$ days $=56$ tablets
b. 4 tablets daily for 4 days $=16$ tablets
c. 40 left $\times 2$ each night $=20$ days

Q2
a. $7.5 \mathrm{mg}$ daily
b. One $\times 2.5 \mathrm{mg}$ tablet + one $\times 5 \mathrm{mg}$ tablet
c. $30 \times 2.5 \mathrm{mg}$ tablets $+30 \times 5 \mathrm{mg}$ tablets $=60$ tablets

Q3
a) $100 \mathrm{ml} \times 6$ hourly $=400 \mathrm{mls}$
b) 2 hrs per day $x 14$ days $=28$ hours
c) 3 daily for 28 days $=84$

Q4

a) $5 \mathrm{mg}$ every 20 minutes $=15 \mathrm{mg} /$ hour $\times 2$ hours $=30 \mathrm{mg}$ 
b) $6 \times 2.5 \mathrm{mg}=15 \mathrm{mg}$

c) $6 \times$ emergency nebs $+6 \times 4$ hourly nebs $=12$ nebs in total

Q5

a) 1 tablet daily $\times 21$ days $=21$ tablets

b) 1 titration

c) 180 tablets

Q6
a) $3000 \mathrm{mg}$
b) $30 \mathrm{mls}$
c) $600 \mathrm{mls}$

\section{References (APA 6 ${ }^{\text {th }}$ Edition)}

British Medical Association (BMA) \& Royal Pharmaceutical Society (RPS) (2019) British National Formulary 78, London: BMJ Group \& Pharmaceutical Press

General Pharmaceutical Council (2019) Standards for the education and training of pharmacist independent prescribers. London: GPhC

Health \& Care Professions Council (2019) Standards for prescribing. London: HCPC

Nursing \& Midwifery Council (2018) Standards for prescribing programmes. London: NMC

Royal Pharmaceutical Society (2016) A competency framework for all prescribers. London: RPS 